\title{
Inflammatory Colitis Due to Methotrexate Toxicity in a Patient With Psoriasis: A Case Report
}

\section{Psoriasis Tanılı Hastada Methotreksat Toksisitesine Bağlı Gelişen Inflamatuar Kolit Olgusu: Olgu Sunumu}

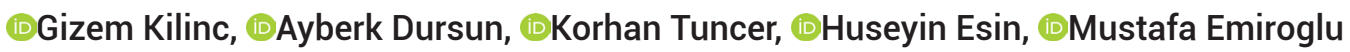 \\ Department of General Surgery, Tepecik Training and Research Hospital, Izmir, Turkey
}

Copyright @ 2021 by authors and Medical Records Publishing Inc.

\begin{abstract}
Methotrexate is known as a folate antimetabolite. The side effects of methotrexate are not usually seen in low dosages. Here we present a patient with inflammatory colitis due to methotrexate use for psoriasis.

A 29 year-old male who was diagnosed with psoriasis 1 year ago and started to use methotrexate for 2 weeks; applied to emergency with acute abdomen symptoms. According to the tests and examinations the patient was diagnosed with inflammatory colitis due to methotrexate toxicity. The patient was observed for abdominal pain without surgical interventions and had folic acid therapy combined with empiric antibiotherapy. Methotrexate side effects are usually seen as bone marrow suppression and mucosal tissue inflammation therefore some side effects can be missed in clinical examinations. As a result, we should consider that in patients applying to emergency with acute abdomen symptoms drugs can be the cause of this clinical presentation.
\end{abstract}

Keywords: Methotrexate toxicity; inflammatory colitis; psoriasis

$\mathrm{Oz}$

Methotreksat folat antimetaboliti olarak bilinen bir ilaç olmakla birlikte yan etkileri yüksek dozlarda görülmektedir. Bu olgu sunumunda psoriasis tanılı bir hastada methotreksat toksisitesine bağlı gelişen inflamatuar kolit tablosundan bahsedilecektir.

Bir sene önce psoriasis tanısı almış ve 2 hafta önce methotreksat tedavisi başlanmış 29 yaş erkek hasta acil servise akut karın semptomları ile başvurdu. Yapılan fizik muayene ve tetkikler sonucunda hastaya methotreksat toksisitesine bağlı inflamatuar kolit tanısı konularak folik asit replasmanı ve ampirik antibiyoterapi başlandı. Hasta opere edilmeden komplikasyonsuz taburcu edildi. Methotreksatın bilinen yan etkileri kemik iliği baskılanması ve mukozalarda inflamasyondur. Acil servise başvuran hastalarda klinik tablonun nedeninin ilaçlar olabileceği akılda bulundurulmalıdır.

Anahtar Kelimeler. Methotreksat toksisitesi; inflamatuar kolit; psoriasis

\section{INTRODUCTION}

Methotrexate(MTX) was produced in 1940s and used as a systemic immunosuppressive agent in 1950s [1]. In course of time its' application was expanded and MTX was started to use for various malignancies, early ectopic pregnancy, chronic inflammatory diseases, some types of carcinoma, rheumatoid arthritis and psoriasis [2,3]. Methotrexate is known as a folate antimetabolite that binds to an enzyme named dihydrofolate reductase, which ultimately leads to inhibition of DNA synthesis. It can be taken as orally, subcutaneously or intramuscularly. MTX primarily bounds to serum albumin and is excreted with urine and can achieve toxic blood levels in patients with hypoalbuminemia and renal failure. In dermatology, typical starting doses of oral methotrexate range from 5 to $15 \mathrm{mg}$ weekly [4]. Toxicity of the MTX at low doses was reported rarely in the literature. In this case report we present a patient with psoriasis diagnosed as inflammatory colitis due to MTX toxicity. 


\section{CASE REPORT}

A 29 year-old male applied to emergency with the symptoms of general abdominal pain, diarrhea and nausea. The patient had diagnosed with psoriasis one year ago and started MTX treatment three weeks before the admission to the emergency department. It was learned that the patient took the drug $20 \mathrm{mg}$ per week for two weeks and stopped the treatment himself when the diarrhea was started. In physical examination defence and rebound was found in lower and upper quadrants of the right abdomen. Also psoriatic plaques were seen on the patient's whole body and limbs. Laboratory tests were analyzed and pancytopenia was found in complete blood count (CBC). The serum albumin and creatinine levels were found to be normal. Due to the acute abdomen symptoms intravenous contrast abdominal computed tomography(CT) was performed. In CT scan right colon wall was found to be thickened whereas no free fluid or air density was seen in abdominal cavity (Figure 1).

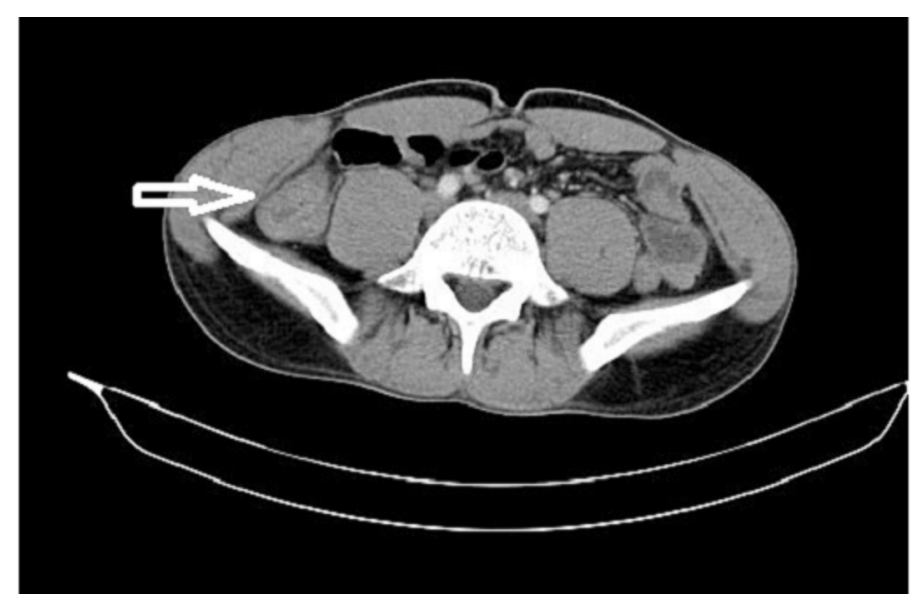

Figure 1. Thickened right colon wall in CT scan

The patient was diagnosed with inflammatory colitis due to MTX toxicity and was hospitalized for observing the abdominal pain. The patient's oral intake and MTX treatment was stopped and intravenous hydration was started. On follow up day 1 the patient had fever therefore blood, stool and urine cultures were sampled and empiric antibiotherapy was started as ceftriaxone combined with metronidazole. On follow up day 2 , oral ulcers were occurred in the patient's oral mucosa and antifungal gargle was given for preventing infections. Dermatology consultation was also done for methotrexate toxicity and treatment of the psoriatic lesions. According to the dermatology consultation folic acid replacement therapy for bone marrow suppression and local pomades containing urea and corticosteroids for skin lesions were started. Colonoscopy was not performed due to the risk of colonic perforation in inflammatory colitis. On patient's follow-up no other complications were seen and the patient was started oral intake according to his regressed abdominal pain. Also CBC controls after folic acid replacement therapy and culture results were found to be normal. The patient was discharged on follow up day 7 without any complications and with planning colonoscopy control.

\section{DISCUSSION}

Although MTX is a relatively safe drug in dosages used in dermatological diseases, side effects associated with idiosyncratic or dose-dependent mechanisms can occur in use of low doses. MTX excrete with urine and can achieve toxic blood levels in patients with hypoalbuminemia and renal failure. Side effects of MTX can be defined as agranulocytosis and bone marrow suppression, mucosal tissue inflammation and necrotic changes, liver cell necrosis and hepatic cirrhosis, pulmonary fibrosis and severe renal dysfunction [5]. Drugs such as aminoglycosides, cyclosporine, nonsteroidal anti-inflammatory agents, sulfonamides, probenecid, salicylates, penicillins, colchicines, cisplatin, proton pump inhibitors can increase the risk of MTX toxicity by decreasing renal elimination of MTX. Also salicylates, probenecid, sulfonamides, barbiturates, phenytoin, retinoids, sulfonylureas, and tetracyclines can increase the risk of MTX toxicity by displacing MTX from protein binding sites in the plasma [6].

Treatment in MTX toxicity depends on the patient's status. Patients who have renal and liver failure, low glasgow coma scores, unstable vital signs must be followed in intensive care units. In treatment, at first step MTX therapy must be terminated and then folic acid replacement therapy must be started for bone marrow suppression. As a result of immunosuppression patients are usually have the risk of infections. In patients with colitis, Clostridium difficile is usually found as an agent in stool cultures. Therefore empiric anti biotherapies must be started for preventing sepsis after taking stool blood and urine cultures in patients with fever.

Whereas oral mucositis were common clinical findings in MTX toxicity, inflammatory colitis was occurred as a rare symptom in our patient. Also physical examination findings were like acute abdomen symptoms. Patient's abdominal pain, oral ulcers and diarrhea were decreased after discontinuation of MTX therapy. We started empiric antibiotherapy due to fever presented in follow up day 2 , gastroenteritis and pancytopenia. Folic acid replacement therapy was also given for bone marrow suppression.

\section{CONCLUSION}

Patients applying to emergency with acute abdomen symptoms, drugs can be the cause of this clinical presentation. Methotrexate toxicity can occur in low doses and early ages therefore patients should be followed more often.

Financial disclosures: All authors report no financial interests or potential conflicts of interest.

Conflict of Interest: There is no conflict of interest related to any person and / or institution.

Informed Consent: Informed consent was taken from the patient. 


\section{REFERENCES}

1. Lawrence D. Atherton, Edward S. Leıb,Mıchael D. Kaye. Toxic Megacolon Associated With Methotrexate Therapy. Gastroenterology. 1984;86:1583-8.

2. Czarnecka-Operacz M, Sadowska-Przytocka A. The possibilities and principles of methotrexate treatment of psoriasis - the updated knowledge. Postepy Dermatol Alergol. 2014;31(6):392-400.

3. Peker A, Yarkıcı H, Akar H. Gastrointestinal bleeding secondary to use of high-dose methotrexate: A case report. J Surg Med. 2018;2(2):151-3.
4. Mrowietz U, de Jong EM, Kragballe $K$, Langley $R$, Nast A, Puig $L$ et al. A consensus report on appropriate treatment optimization and transitioning in the management of moderate-to-severe plaque psoriasis. J Eur Acad Dermatol Venereol. 2014;28(4):438-53.

5. Demir FT, Tezcan Y, Türkoğlu Z, Başaran Ş. A case of Severe Low-dose Methotrexate-induced Toxicity. Med Bull Haseki. 2016;54:252-4.

6. Jariwala P, Kumar V, Kothari K, Thakkar S, Umrigar DD. Acute Methotrexate Toxicity: A Fatal Condition in Two Cases of Psoriasis. Case Reports Dermatol Med. 2014;2014:946716. 